\title{
SAWHOYAMAXA COMMUNITY V PARAGUAY: A GOOD EXAMPLE OF EFFECTIVE STRATEGIC LITIGATION AND ADVOCACY ${ }^{1}$
}

\author{
SOFÍA MARURI ARMAND-UGÓN*
}

"Without our land, we are dead. We want to return to our land"

Aparicia González

\section{Introduction}

Over the last decades, the rights of indigenous peoples have gained significant visibility and recognition in international and regional instruments and institutions. For instance, the International Labor Organization approved the Convention No. 169 concerning Indigenous and Tribal Peoples in Independent Countries in 19892; the United Nations established the UN Permanent Forum on Indigenous Issues in 2000 as a high-level advisory body to the Economic and Social Council and also adopted the UN Declaration on the Rights of Indigenous Peoples in $2007^{3}$, which deals with aspects of strengthening the distinctiveness of indigenous societies within the institutional frameworks of existing States ; and american states approved the American Declaration on the Rights of Indigenous Peoples in $2006^{5}$.

Furthermore, national, regional, and international courts have received numerous cases concerning the rights of indigenous peoples. Rights to land and natural resources have been among the most litigated and contentious issues for indigenous peoples across the globe 6 . They serve the purpose of protecting indigenous identity as defined by the cultural and spiritual attachment of a community to its traditional lands ${ }^{7}$. One case regarding these issues is that of Sawhoyamaxa Community $v$ Paraguay, litigated before the Inter-American Court of Human Rights. It represents a proper example of effective strategic litigation and advocacy as it made social, political, and legal contributions to the advancement of land rights in the region and worldwide.

\footnotetext{
* Abogada. Mst (c) in International Human Rights Law, University of Oxford. Profesora aspirante de “Derechos Humanos" en la Facultad de Derecho de la Universidad de Montevideo (Uruguay). ORCID id: http//orcid.org/0000-00029745-7191.m.maruri@um.edu.uy

1 El siguiente artículo fue presentado como ensayo dentro de la materia "Fundamentals of International Human Rights Law" en la Maestría de Derecho Internacional de los Derechos Humanos en la Universidad de Oxford, en Marzo de 2020.

2 Adopted on 27 June 1989, C169, available at: https:/ / www.ilo.org/dyn/normlex/en/f?p=NORMLEXPUB:12100:0::NO::P12100_ILO_CODE:C169 (accessed March 22, 2020)

3 UN Doc. A/Res/61/295. Adopted on 13 Sept. 2007 by a vote of 143 in favour, 4 against (Australia, Canada, New Zealand, and US), and 11 abstentions.

4 Daes, p. 38.

5 OAS AG/RES.2888 (XLVI-O/16): adopted at the thirds plenary session, held on June 15, 2016).

6 Strategic Impact 2018, p. 23.

7 Pentassuglia 2011, p. 167.
} 


\begin{abstract}
About the case
The Sawhoyamaxa Community has historically lived in the Paraguayan Chaco. In 1991, the community initiated domestic claims for land restitution after being forced to leave their land. The process turned ineffective so they filed for legal expropriation of the land, by making an expropriation request in 1997, that did not succeed.
\end{abstract}

The community petitioned the Inter-American Commission of Human Rights in 2001 and then their case was filed before the IACtHR on February 2005. In March 2006, the Court found various violations of the American Convention on Human Rights ${ }^{8}$, specifically art. 8 and 25 (right to a fair trial and judicial protection), art. 21 (right to property), art. 4(1) (right to life) and art. 3 (right to recognition as a Person before the Law), all of them in relation to art 1(1) (the obligation to respect rights).

The IACtHR ordered very specific remedies ${ }^{10}$ : to return the ancestral lands to the community; to create a development fund for the community; and to pay compensation for non-pecuniary damages, costs, and expenses within one year. It called on the state to deliver basic goods and services and implement an emergency communication system as long as the community remained without land.

Although the decision of the IACtHR ordered the restitution of the disputed land to the community within three years, the authorities did not adopt an order of expropriation for the cattle ranchers living on their land until 2014. It was in this year when the Congress passed and the President signed a bill expropriating the land and officially returning it to the Sawhoyamaxa.

\title{
The case as a good example of strategic litigation and advocacy
}

The Executive Summary on "Strategic Litigation Impact: Indigenous Peoples' Land Rights" published by Open Society Foundations purposes that strategic litigation is the one that positively affects persons beyond the individual complainants before the court. It is one of many social-change tools, and is often used in concert with public protests, lobbying, legal aid, and other forms of advocacy ${ }^{11}$ : as happened with the case that is being analyzed in this essay.

Sawhoyamaxa Community v Paraguay represents a good example of effective strategic litigation and advocacy due to various reasons: a) the indigenous community won the case, $b$ ) it set legal precedents for future litigations on matters of land rights, c) it signified changes in attitudes and behaviors towards this issue and d) it effectuated political reforms. The four reasons will be studied bellow.

8 IACtH, Sawhoyamaxa Indigenous Community v. Paraguay, Judgment of March 29, 2006, para. 248.

9 "Case of the Sawhoyamaxa Indigenous Community v. Paraguay", available at https://www.escr-net.org/caselaw/2013/case-sawhoyamaxa-indigenous-community-v-paraguay (accessed March 21, 2020).

10 IACtH, Sawhoyamaxa Indigenous Community v. Paraguay, para. 204-247.

11 Strategic Litigation 2017, p. 24 


\section{a) The indigenous community won the case}

Although the Sawhoyamaxa Community won the case before the IACtHR, they did not get their land back rapidly and easily. However, the case was a helpful tool for the community seeking to defend its culture and traditional lands. The legal win inspired confidence and set into motion to the advocacy tools through media campaigns and non governmental bodies which brought wider societal change in attitude and behaviors.

In this case, the "win" was not the end event of litigation. A robust post ruling strategy and a long-term involvement of litigators was vital. The change sought and its enforcement was initiated by the win, as "a court's decision is in many ways the beginning of the battle, rather than the end of a process"12.

\section{b) The case set legal precedents for future litigations on matters of land rights}

The case had a significant repercussion on jurisprudence as it set strong legal precedent which was cited in future similar cases involving land rights for the indigenous people.

As Pentassuglia states "the jurisprudence generated in this context reaches out to a significant sector of the international community which has undertaken obligations under those regimes, and empowered judicial or quasi-judicial bodies to interpret and apply them. Such treaties, ranging from the ICCPR, to the $A C H R$, to the $A f r C H$, provide a wide context of rights within which indigenous land considerations can be diffused"13.

One of the cases that cited Sawhoyamaxa Community $v$ Paraguay in its judgement was Xákmok Kásek Indigenous Community v Paraguay in 2010, also before the IACtHR, which obtained a favorable ruling on similar grounds ${ }^{14}$. Another one was that of Endorois v. Kenya in $2009^{15}$, were the African Commission of Human Rights, using its Article 60 of the African Charter to draw on non-African sources of international law, cited the Sawhoyamaxa case jurisprudence to assist in more clearly articulating the concept of collective rights and rights to property over the land, natural resources and development. Recent ACHPR jurisprudence indicates a progressive alignment with international jurisprudence, most notably from the Inter-American system ${ }^{16}$, and this concrete case is an example of it.

It had also an impact on the legal profession as both judges and lawyers may now learn about land rights cases from this case and from "cases in other jurisdictions, and use cases from across the globe to support their legal reasoning. Evidence shows that precedents can affect not only judges, but also lawyers and potential plaintiffs ${ }^{17 "}$.

2 Strategic Litigation 2017, p. 77.

13 Pentassuglia 2011, p. 199

14 IACtH, Case of the Xákmok Kásek Indigenous Community v Paraguay, judgment of August 24, 2010, para. 110 and 137.

15 ACHPR, Minority Rights Dev. v Kenya, Nov. 2009, para. 197 and 208. See also reference in Pentasuglia 2011, p. 187.

16 Pentassuglia 2010, p. 154.

17 Strategic litigation 2017, p. 53. 


\section{a) It signified changes in attitudes and behaviors toward indigenous peoples and} their land rights issues

Sawhoyamaxa Community $v$ Paraguay was a collective case, which sought remedies for a larger community rather than an individual or a family. It concerned collective land claims, which play a very important role in the collective identity of indigenous peoples.

After the ruling, the Sawhoyamaxa Community received greater exposure, nationally and internationally. It supposed a change in the public opinion regarding indigenous peoples' rights and helped to build awareness among indigenous communities. This can be appreciated in the creation of an indigenous organization in Paraguay: The Coordinator of Indigenous Leaders from Lower Chaco, which represents over 50 indigenous communities in the region.

This pan-indigenous organization supports other indigenous groups in their efforts to promote implementation of their received rulings. They assist them by letting them know that the IACtHR exists and can support indigenous rights; that there are rulings which have been made as a means of admonishing the state; that indigenous peoples have avenues to gain support for their claims. This show how the impacts of strategic litigation can affect even also groups not directly involved in the case ${ }^{18}$.

\section{b) It effectuated political reforms: institutions, legislation and policies}

The case had considerable influence on the institutional makeup of the state, as the government of Paraguay established a special institution in charge of supporting the implementation of international rulings: The Inter-institutional Commission Responsible for the Execution of Necessary Actions for Compliance with International Rulings and Recommendations or CICSI (in its Spanish acronym). Since its establishment, CICSI has been in charge of reporting progress regarding implementation of the judgments of the IACtHR. The creation of CICSI was significant and reflected a change in the government's attitude toward complying with international rulings ${ }^{19}$.

What is more, there was a Presidential Decree 4367 of 2015, which restructured CICSI making it drawn under the control of the Ministry of Exterior. The first sentence of the body of the Decree begins stating "In light of the international rulings from the Inter-American Court of Human Rights and the recommendations from the Inter-American Commission on Human Rights": explicit language which reflects that CICSI was formed in large part due to this ruling, among others against Paraguay from the IACtHR ${ }^{20}$.

Paraguay's President Cartes signed into law an Expropriation Bill to return the lands to the Sawhoyamaxa people on June $11,2014^{21}$ after it passed through the House and Se-

18 Strategic Litigation 2017, p. 66

19 Strategic Litigation 2017, p. 57.

20 Such rulings are: Yakye Axa Community v Paraguay and Xákmok Kásek Community v Paraguay.

21 Paraguayan Law No 5194. 
nate after months of protests alleging that the IACHR order had remained unfulfilled ${ }^{22}$. This marked the end of a long journey that the community had to fight for over 20 years.

\section{Implementation of judgments are the weak arm of the judicial system}

Hafner-Burton and Tsutsui understand that "human rights treaties are most effective when ratified by states with democratic systems of government or strong civil society advocates"23. Although Paraguay is a democratic state, it needed a strong group of people to advocate for the implementation of this case.Paraguay's delay in putting into practice the IACtHR's decision reflects that the implementation of judgements tend to be the weak arm of the judicial system. Also that monitoring, reporting and follow up procedures are needed to ensure that the government does fulfill its duties.

The litigation of this case and its victory at the regional level function as a reminder that, until the domestic legal system is improved, the country will continue to face cases on land rights in international forums and will encourage other communities to do so.

\section{Conclusion}

The case began as a land claim and after reaching the Inter-American System became "strategic" in the sense of serving as a vehicle for broader social change beyond the claimant community and also other communities.

The decision and its post judicial procedure demonstrated that "strategic human rights litigation" is a process, not a single legal intervention, even not just winning the case before an international court. "More than a final judgment, strategic litigation is in fact a series of phased actions, from case development, to hearings and ruling, to post-judgment implementation (or its absence)" 24 . In this case, the ruling of the IACtHR was the initial kick-off.

While litigators were required and vital so as to get the "win", strategic litigation is most effective when carried out principally for, and together with, non-litigators ${ }^{25}$. Although its delay implementation, Sawhoyamaxa Community $v$ Paraguay is a landmark decision which confirms the importance and effectiveness of advocacy work, which includes protests, research, media campaigns, legislative and administrative lobbying, strategic alliances, and even the arts. All prove to be useful tools for social change and to fix state responsibilities to ensure non-repetition and development of laws and policies.

\footnotetext{
22 News regarding this issue can be found at: https://www.americasquarterly.org/content/paraguayan-supreme-court-issue-ruling-expropriation-law (accessed March 25, 2020); https://www.theguardian.com/environment/ andes-to-the-amazon/2014/oct/07/paraguay-supreme-court-historic-land-ruling (accessed March 25, 2020); https:// www.bbc.com/mundo/ultimas_noticias/2014/05/140522_ultnot_paraguay_expropiacion_indigenas_vs (accessed March 25, 2020).

23 Hafner-Burton and Tsutsui, p. 418.

24 Strategic litigation 2018, p. 19.

25 Strategic litigation 2018, p. 33.
} 


\section{Bibliography}

Daes, Erica-Irene, "The UN Declaration on the Rights of Indigenous Peoples: Background and Appraisal. Reflections on the UN Declaration on the Rights of Indigenous Peoples", Ed. Stephen Allen and Alexandra Xanthaki. London: Hart Publishing, 2011. $11-40$.

Dersso, Solomon, "Perspectives on the rights of minorities and indigenous peoples in Africa", Pretoria University Law Press (PULP), 2010.

Executive Summary on "Strategic Litigation Impact: Indigenous Peoples' Land Rights" published by Open Society Foundations, april 2017. Available at: https:// www.justiceinitiative.org/publications/strategic-litigation-impacts-indigenous-peoples-land-rights (acceded March 17, 2020).

Executive Summary on "Strategic Litigation Impacts: Insights from Global Experience" published by Open Society Foundations, february 2018. Available at: https:/ / www. justiceinitiative.org/uploads/fd7809e2-bd2b-4f5b-964f-522c7c70e747/strategic-litigation-impacts-insights-20181023.pdf (acceded March 22, 2020).

Hafner-Burton, Emilie M. and Tsutsui, Kiyoteru, "Justice Lost! The Failure of International Human Rights Law to Matter Where Needed", Journal of Peace Research, Vol. 44, No. 4, Special Issue on Protecting Human Rights (Jul., 2007), pp. 407-425

Núñez Poblete, Manuel A., "The constitution of indigenous property as a goal of expropriation by national interest", Rev. Derecho (Valdivia), vol.30 no.,1 Valdivia jun. 2017.

Pentassuglia, Gaetano, "Indigenous Groups and the Developing Jurisprudence of the African Commission on Human and Peoples' Rights: Some Reflections." UCL Human Rights Review, 3, 2010, p. 150-163.

Pentassuglia, Gaetano, “Towards a Jurisprudential Articulation of Indigenous Land Rights". European Journal of International Law, Volume 22, Issue 1, February 2011, Pages 165-202.

Tauli-Corpuz, Victoria, "Report of the Special Rapporteur on the Rights of Indigenous Peoples: The Situation of Indigenous Peoples in Paraguay", 2015.

\section{Legislation:}

UN Declaration on the Rights of Indigenous Peoples, G.A. Res. 61/295, U.N. Doc. A/ RES/47/1 (2007). Available at: http:/ / hrlibrary.umn.edu/instree/declaration.html (last visit March 23, 2020).

American Declaration On The Rights Of Indigenous Peoples, adopted at the third plenary session of the Gral. Assembly of the OAS, held on June 15, 2016. Available at: https:/ / www.oas.org/en/sare/documents/DecAmIND.pdf (last visit March 22, 2020). 
Convention No. 169, International Labor Organization, adopted on 27 June 1989, available at: https://www.ilo.org/dyn/normlex/en/f?p=NORMLEXPUB:12100:0::NO::P12100_ILO_CODE:C169 (accessed March 22, 2020)

Paraguayan Law No 5194, available at: http://www.bacn.gov.py/leyes-paraguayas / 4640/declara-de-interes-social-y-expropia-a-favor-del-instituto-paraguayo-del-indigena-indi-para-su-posterior-adjudicacion-a-la-comunidad-indigena-sawhoyamaxadel-pueblo-enxet-la-finca-n-16786-padron-n-12935-con-una-superficie-de-9105-hectareas-con-2978-metros-cuadrados-y-la-finca-n-16784-padron-n-12936-con-una-extension-de-5299-hectareas-con-4720-metros-cuadrados-ambas-del-distrito-de-villa-hayes-pozo-colorado-del-departamento-presidente-hayes-chaco-pertenecientes-a-las-firmas-kansol-sa-y-roswell-y-cia (accessed Match 25, 2020).

\section{Jurisprudence:}

Inter-American Court of Human Rights, Case of the Sawhoyamaxa Indigenous Community v. Paraguay, Judgment of March 29, 2006. Available at: http:/ /www.corteidh. or.cr/docs/casos/articulos/seriec_146_ing.pdf (accessed March 21, 2020).

Inter-American Court of Human Rights, Case of the Xákmok Kásek Indigenous Community v Paraguay, Judgment of August 24, 2010. Available at: https:/ /www.corteidh. or.cr/docs/casos/articulos/seriec_214_ing.pdf (accessed March 21, 2020).

ACHPR, Minority Rights Dev. v Kenya, Comm. 276/2003, 27th ACHPR AAR Annex (Jun 2009 - Nov 2009), para. 197 and 208. Available at: http:/ /www.worldcourts.com/ achpr/eng/decisions/2009.11_CMRD_v_Kenya.htm (accessed March 24, 2020). 